\title{
A SZEGVÁR-SÁPOLDALI 1. SÍR KELETI KAPCSOLATAI AZ ÚJABB OROSZ ÉS UKRÁN KUTATÁS FÉNYÉBEN
}

\author{
GULYÁS BENCE*
}

Bóna István a szegvár-sápoldali 1. sírt az avarság első generációjához sorolta. Ennek megfelelően a temetkezési szokások és a mellékletek keleti párhuzamait keleten, föleg Közép- és Belső-Azsiában kereste. Ugyanakkor az új eredmények fényében a sápoldali halott kulturális gyökerei KeletEurópában, a Sivašovka-típusú temetkezések elözményei között keresendők. A sírban talált tárgyak kapcsolatai nem ázsiai, sokkal inkább közép-kelet-európai kontextusban értelmezhetök.

Kulcsszavak: Szegvár-Sápoldal, kora avar kor, Belső-Ázsia, Közép-Ázsia, Sivašovka-típusú temetkezések

According to István Bóna, the Grave Nr. 1. in Szegvár-Sápoldal belonged to the first generation of the Avars. Therefore he looked for the analogies of its burial customs and its grave goods in the east, mainly Central and Inner Asia. However, in the light of the new results, the cultural roots of the person who was buried in Sápoldal can be found in Eastern Europe, among the antecedents of the Sivashovka type burials. The connections of the grave goods can be interpreted not in Asian, but in an East-Central European context.

Keywords: Early Avar Age, Szegvár-Sápoldal, Inner Asia, Central Asia, Sivashovka type burials

Bóna István a szegvár-sápoldali sír kapcsán egy történeti narratívának, az 567/68-as avar honfoglalásnak a régészeti nyomait próbálta meghatározni. Ennek nyomán mind a temetkezési szokások, mind a mellékletek keleti párhuzamaira összpontosított. Széleskörû́ szakirodalmi tájékozottságának köszönhetően eredményei több esetben a mai napig megállják a helyüket, de a sápoldali sír némely analógiáinak felülvizsgálatát a posztszovjet régészet elmúlt évtizedekbeli fejlődése lehetővé és szükségessé is teszi.

A türk kori régészetben sokáig az egyik legnagyobb problémát a jól kidolgozott kronológiai rendszerek hiánya jelentette. Az 1990-es évektől kezdve a belsó-ázsiai kutatás fokozatosan pótolta ezt az elmaradást. Az avar kor kutatása szempontjából a legjelentősebb az ún. Kyzyl-Taš horizont meghatározása, amelyet az 5. század máso- dik és a 6. század első felére, azaz az avar honfoglalást megelőző időszakra tesznek. ${ }^{1}$ E csoport anyagi kultúrája sok egyezést mutat a kora avar kor legkorábbi emlékanyagával (1. kép). Mivel a horizonthoz tartozó leletegyüttesek túlnyomó többsége áldozati leletekból és kenotáfiumokból származik, nem szolgál analógiákkal a temetkezési szokásokat illetóen.

A sápoldali sír kapcsán fontosabbak a keleteurópai párhuzamok. Csallány Dezső nyomán Lőrinczy Gábor különített el egy olyan kora avar kori népességet, mely a Tiszántúlon viszonylag

\footnotetext{
A kézirat beérkezett: 2018. február 29.

* Gulyás Bence: ELTE BTK Régészettudományi Intézet, 1088 Budapest, Múzeum krt. 4/b; e-mail: gbence567@gmail.com 1 TIŠKIN-SEREGIN 2011.
} 


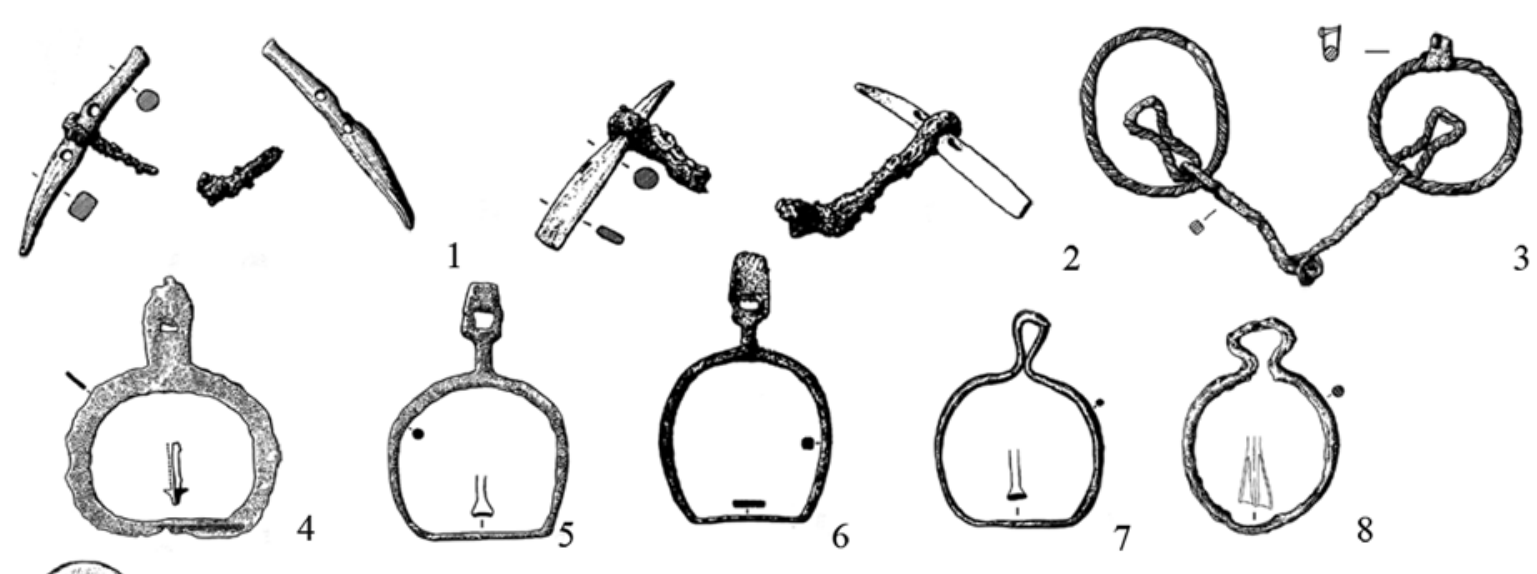

3
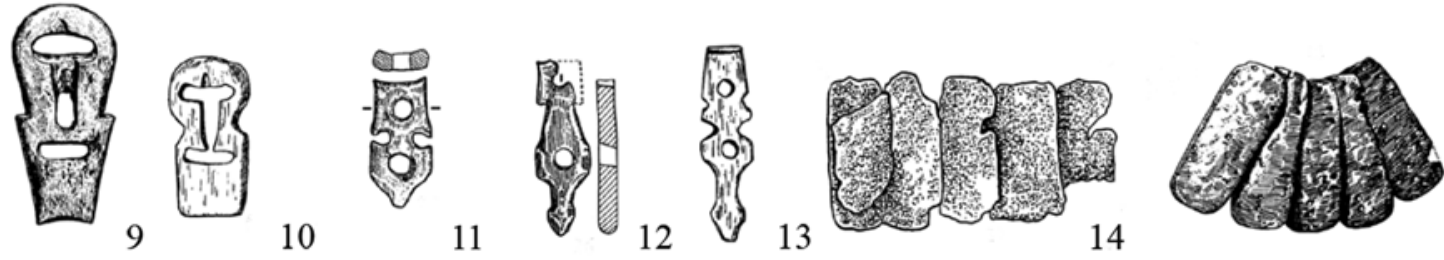

1. kép. A Kyzyl-Taš horizont jellemző tárgytípusai: 1. Kara-Koba, 86. ogradka; 2. Kara-Koba, 88-2. ogradka; 3, 10, 13. Borotal I, 82. kurgán; 4. Kok-Paš, ogradka A-2; 5. Kok-Paš, ogradka A-3; 6. Kara-Koba I, 76. ogradka; 7. Ust'-Karasu, ogradka A-2; 8. Tytkesken' 6, 5. kurgán; 9. Ust'-Biyke III, 5. kurgán; 11-12. Yakonur, 5. kurgán; 14. Kok-Paš, 1. kurgán; 15. Kudyrge, ogradka XIII. (TIŠKIN-SEREGIN 2011 nyomán)

Fig. 1. Characteristic finds of the Kyzyl-Tash horizon's sites: 1. Kara-Koba, Ogradka 86; 2. Kara-Koba, Ogradka 88-2; 3,10,13. Borotal I, Mound 82; 4. Kok-Paš, Ogradka A-2; 5. Kok-Paš, ogradka, A-3; 6. Kara-Koba I, ogradka 76; 7. Ust'-Karasu, ogradka A-2; 8. Tytkesken' 6, Mound 5; 9. Ust'-Biyke III, Mound 5; 11-12. Yakonur, Mound 5; 14. Kok-Paš, Mound 1; 15. Kudyrge, Ogradka XIII. (after TišKIN-SEREGIN 2011)

egy tömbben telepedett le. Ez a csoport nem az anyagi kultúrájával, hanem a jellegzetes temetkezési szokásaival különül el a Kárpát-medence többi sztyeppei eredetú népcsoportjától. Ezek a rítuselemek együttesen még a 6-7. századi keleteurópai sztyeppén fordulnak elő (2. kép), így a tiszántúli kora avar kori népesség eredete is itt keresendő. ${ }^{2}$ A Déli-Bug és a Volga közötti terület kora középkori nomád leletanyagának módszeres kutatása a nyolcvanas években kezdődött meg, azóta mintegy 160 temetkezés vált ismertté. A Šipovo-típusú temetkezések az avar kort megelőző időszakra, az 5. század második, a 6. század első felére, míg a Sivašovka-típusú sírok a 6. század második felére és a 7 . századra keltezhetók. ${ }^{3}$ A két csoport kutatottsága nem egyenletes, míg az előbbihez csupán pár tucat sír sorolható, addig az utóbbihoz majdnem 120 temetkezés tartozik. ${ }^{4}$

A továbbiakban a fenti adatok fényében a szegvár-sápoldali 1. sír keleti párhuzamait vizsgálom kitérve mind a temetkezési szokásokra,

2 További szakirodalommal GULYÁs 2015, 499-500.

3 BEREZUTSKY-MASTYKOVA 2016, 224, 4. j.

4 Vö. KAZANSKI 2017, 98, ris. 1.; RAŠEV 2005, 71-89. mind a tárgytípusokra. Terjedelmi korlátok miatt nem térhetek ki az összes jelenség elemzésére, ezért csupán a legfontosabbakat említem.

\section{A sápoldali 1. sír analógiái}

\section{Temetkezési szokások}

Tájolás. A kora avar kori tiszántúli temetkezések esetében a K-Ny-i és az ÉK-DNy-i tájolás dominált. ${ }^{5} \mathrm{~A}$ halottak ilyen irányú fektetése a Sivašovka-típusú temetkezések döntő többségénél is megfigyelhetó (2. kép 1, 3). ${ }^{6}$ Ugyanakkor meg kell említeni, hogy a jelenség nem csak Kelet-Európára jellemző. Belső-Ázsiában az 1. évezred első felében a Ny-K-i, É-D-i és a K-Ny-i tájolás egyaránt jelen volt. ${ }^{7}$ A türk időszakra a tájolás egységesül, a sírok $70 \%$-a K-Ny-i irányítású. ${ }^{8}$

\footnotetext{
5 LÖRINCZY 2016, 156-157.

6 Vö. KOMAR-KUBYŠEV-ORLOV 2006, 362, ris. 50.

SEREgIN-MATRENIN 2016, 55-56.

8 SEREgIN 2013, 43.
} 

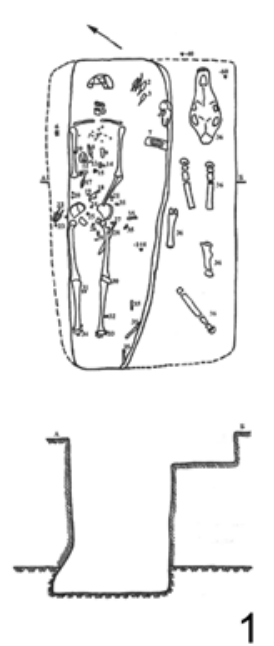
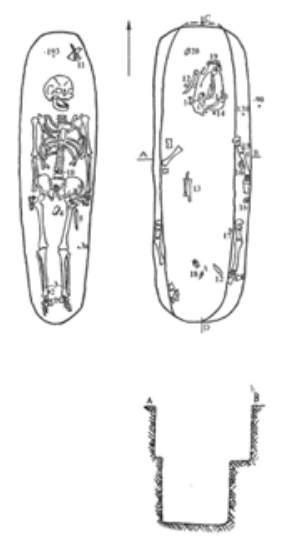

2

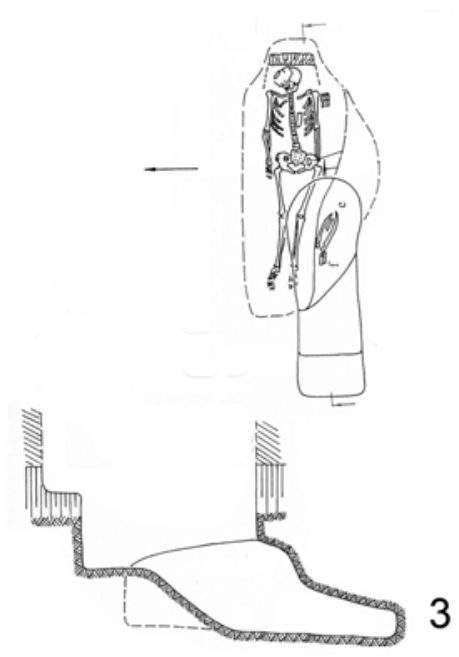

3

2. kép. Példák a Sivašovka-típusú temetkezésekre: 1. Kostogryzovo 7. kurgán, 1. sír; 2. Sivašskoe 2. kurgán, 2. sír; 3. Khristoforovka 7. kurgán, 12. sír (KOMAR-KUBYŠEV-OrLOV 2006 és PRIHODNYUK-FORMENKO 2003 nyomán)

Fig. 2. Examples of the Sivashovka-type burials: 1. Kostogryzovo, Mound 7, Grave 1; 2. Sivashskoe, Mound 2, Grave 2; Kristoforovka, Mound 7, Grave 12. (After KOMAR-KubYŠEv-Orlov 2006 and PrIHODNYUK-FormenKO 2003)

Sírforma. Bóna István a sápoldali sírt a Kiss Attila-féle tipológiában a VIII. típusba sorolta, azaz rekonstrukciója szerint a lovak a halott lábánál, vele egy tengelyben helyezkedtek el. ${ }^{9}$ Lórinczy Gábor meggyőzően érvelt amellett, hogy a temetkezés eredetileg fülkesír lehetett. ${ }^{10}$ Ez a sírforma ismeretlen mind Belső-Ázsiában, mind Kelet-Európában, ezért Bálint Csanád szerint kialakulása már a Kárpát-medencében történt. ${ }^{11} \mathrm{Az}$ egyetlen hasonló temetkezés a Feketetenger északi partvidékéről, Khristoforovka 7. kurgán 12. sírja. Ebben az esetben a fülke és az akna nem egy tengelybe esett, így az a padmalyos és fülkesír közötti átmenetként értelmezhető (2. kép 3). 12

Egész ló. A belső-ázsiai türk temetkezések szinte kivétel nélkül egész ló maradványait tartalmazták. Az egész lóval való temetkezés az Altajban a Kr. e. 2.-Kr. u. 5. századra keltezett Bulan-Koby kultúra területén már megjelent. ${ }^{13}$ A szokás csúcspontja a türk korra tehetó, amikor már a temetkezések több mint $70 \%$-ában találtak lovat. ${ }^{14}$

Az elmúlt években az avar honfoglalást megelőző időszakból egyre több temetkezés látott napvilágot Kelet-Európában is, melyek teljes lóvázat tartalmaztak (Dmitrievka - Vol'novaâ Voda, Lis'i Mogil'a, Neyzats 114. sír). ${ }^{15}$ Ugyan-

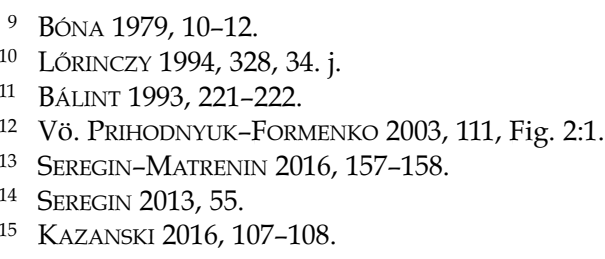

akkor a későbbi időszakban sem vált az egész ló eltemetése általánossá, az Aleksei Komar által vizsgált lelóhelyek 10,3\%-ában tudták kimutatni a szokás jelenlétét. ${ }^{16}$ A legfontosabb lelőhelyek Sivašovka 3. kurgán, 2. sír, Portovoe 12. kurgán, 5. sír és Vinogradnoe 5. kurgán, 3. sír; ${ }^{17}$ az újabban publikált temetkezések közül Vostočny Malai 1. kurgán, 12. sír ${ }^{18}$ és Greki I 1. kurgán, 6. sír említhetó meg. ${ }^{19}$ A 6-7. században az egész lovak sírba helyezése egyértelmúen a halott kiemelkedő státuszával állhat összefüggésben, amire a sírokban talált fegyverek is utalhatnak. ${ }^{20}$

Részleges ló. Bóna István kimutatta, hogy a részleges lovas temetkezések Belső-Ázsiában ismeretlenek, így a sírba helyezésük szokását az avarok valahol Kelet-Európában vehették át. ${ }^{21}$ Később azonban változtatott véleményén, és a kazahsztáni Baraba-sztyeppéról közölt temetkezések alapján mégis felvetette a szokás ázsiai eredetét. ${ }^{22} \mathrm{Az}$ ott talált temetkezések azonban az ún. Potčevaš-kultúrához köthetők, ami nem nomád, hanem egy nyugat-szibériai őslakos kultúra. ${ }^{23}$

\footnotetext{
16 KOMAR-KubYŠEV-ORLOV 2006, 314.

17 KOMAR-KubYŠEV-ORLOV 2006, 264.

18 A sírban lévő két lovat megbolygatták, de a megtalált csontok alapján (koponya, lábcsontok, farokcsigolyák, borda és lapocka) kizárhatjuk, hogy részleges lovas temetkezésekről lenne SZó. LIMBERIS-MARČENKO 2012, 421-422.

19 ČKHAIDZE 2011, 116.

20 RAŠEV 2005, 94-95.

21 BÓNA 1979, 20.

22 BÓNA 1990, 116.

23 DEREVÂNKO 1988, 3-4.
} 
A részleges lovas temetkezés a kultúra esetében nem meglepő, ugyanis az Urál vidékén (Azelinokultúra) ${ }^{24}$ és Nyugat-Szibériában (Ryolka-kultúra ${ }^{25}$ is ismert a szokás. Ez nem mondható el Belső-Ázsiáról, ahonnan a türk korban egy esetet leszámítva nem ismert a lóáldozat ezen formája. ${ }^{26}$

Ezzel szemben a szokás széles körben elterjedt Kelet-Európában, ahol a hun korban jelent meg. A legtöbbet a 6-7. századból ismerjük, Aleksei Komar szerint a rítuselem a Sivašovka-típusú sírok több mint harmadára jellemző $(1$. kép 1, 2).27 A sápoldali sírt nem csupán a részleges ló megléte kapcsolja Kelet-Európához, hanem a nyúzás módja is. A Tiszántúlra a kora avar korban az ún. csonkolásos módszer jellemző. ${ }^{28}$ Ezt a technikát Andrei Atavin a Kubán-vidéki temetkezések kapcsán is dokumentálta. ${ }^{29}$

Több ló a sírban. A sápoldali 1. sírból két ló maradványai kerültek elő. Az egyszerre több állat sírba helyezése a Tiszántúlon általánosnak mondható. Lőrinczy Gábor megfigyelte, hogy a korai sírokra ez a jelenség nem jellemző, a sok állatot tartalmazó temetkezések csak a 7. században terjedtek el. ${ }^{30}$ Kelet-Európából nem ismert a lovak halmozásának a szokása, mindösszesen a Vostočny Malai 1. kurgán, 12. sír említhető meg, amelyben - a bolygatottság ellenére - két egész ló maradványait lehetett dokumentálni. ${ }^{31}$ Bóna István a több ló sírba helyezése kapcsán leírta, hogy ez Belső-Ázsiában is ritkán fordul elő, és a gazdagság jeleként kell értelmezni. ${ }^{32}$ Ez a megállapítása azóta is helytálló. ${ }^{33}$ Maga a szokás az Altaj vidékén sem elterjedt, három sírban háromhárom, míg Balyk-Sook I 11. kurgánban négy ló volt. Ezekben az esetekben nem mindig volt az összes állat felszerszámozva. ${ }^{34}$ Ezek kizárólag férfitemetkezések voltak. ${ }^{35}$

Obulus. A temetkezésből Mauricius Tiberius solidusának utánzata került elő, mely nem ékszerként, hanem obulusként kerülhetett a sírba. Bóna István számos példával támasztotta alá az obulus adásának ázsiai eredetét. ${ }^{36}$ Meg kell azonban jegyeznünk, hogy a korai példái nem BelsőÁzsiából, hanem a szomszédos régiókból származnak. Jelen tudásunk szerint összesen kilenc

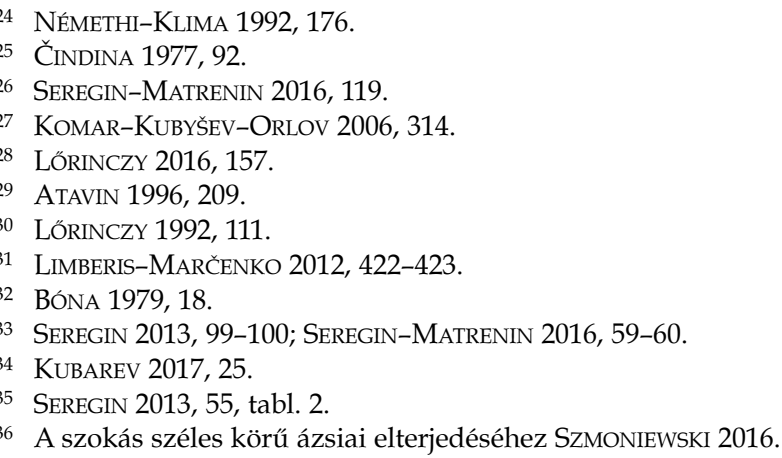

türk temetkezésből ismerünk kínai érmet, egy kivételével azonban azok a 7-9. századból származnak. ${ }^{37}$

Kelet-Európából a Yosipovka 24. sírból és Žuravlikháról ismerünk bizánci solidusokat, előbbi lelőhelyen egy Heraclius- és Heraclius Constans-, utóbbin egy II. Constans-érme került elő. ${ }^{38}$ Ezek azonban nem obulusként kerültek a sírba, a rajtuk lévő perforáció alapján ékszerként, nyakban viselték őket.

Koporsó. Bóna István véleménye, miszerint a sztyeppei népek a koporsókapcsokat a Kárpátmedencében vehették át, ${ }^{39}$ a mai napig érvényes, a cikke megírása óta sem került elô a tárgytípus Kelet-Európából vagy Belső-Ázsiából.

\section{Mellékletek}

Veretes homlokpánt. Bóna István a veretes homlokpántok esetében a közép-ázsiai képi ábrázolások mellett egy tuvai temetkezést hozott fel analógiaként. Mongun-Tajga 58-VIII. sírt azonban az újabb kutatás nem keltezi a 7. század középső harmadánál korábbra. ${ }^{40}$

Gúlacsüngős fülbevaló. A koponya bal oldalán egy gúlacsüngős fülbevaló helyezkedett el. A fülbevalók pár nélküli viselését Bóna ázsiai eredetú hagyománynak tartotta, amire számos példát hozott. 41

A gúlacsüngős fülbevalók eredetéról megoszlanak a vélemények. Az előkerült darabok közül Garam Éva csak a kisméretű öntött darabokat tartotta bizánci gyártmánynak. ${ }^{42}$ Ezzel szemben Kovrig Ilona, Bóna István, Bálint Csanád és Balogh Csilla a nagyobb, aranyból készült préselt fülbevalókat is a Mediterráneumból eredeztette. ${ }^{43}$ Bár kétségtelen, hogy a prototípusok a Földközi-tenger medencéjéból származnak, ${ }^{44}$ a 6-7. századi darabok Kelet-Európából, főként a Kaukázusból ismertek. Sztyeppei eredetú temetkezések közül a kelegeâi, az artsybaševói és a glodosyi tartalmazott gúlacsüngós fülbevalót (3. kép 3-5). ${ }^{45}$ A keleteurópai és a Kárpát-medencei példányok a kísérőleleteik alapján egykorúak, ezért a típus elterjedésének pontos iránya ma még nem határozható meg.

\footnotetext{
37 TIŠKIN-SEREGIN 2013, 51. tabl. 1.

38 További hivatkozásokkal KOMAR 2006, 405-406.

9 BÓNA 1979, 15.

40 STARK 2009, 122.

41 BÓNA 1979, 27. Kelet-Európában egyedül Vostočny Malai 1. kurgán 12. sírban találtak a halott halántékának bal oldalán arany fülbevalót. LIMBERIS-MARČENKO 2012, 423.

42 GARAM 2001, 29.

43 BÓNA 1980, 42; BALOGH 2014, 93-94.

44 További irodalommal BALOGH 2014, 92-93.

45 BÁLINT 1993, 256-258, Fundliste 2.
} 


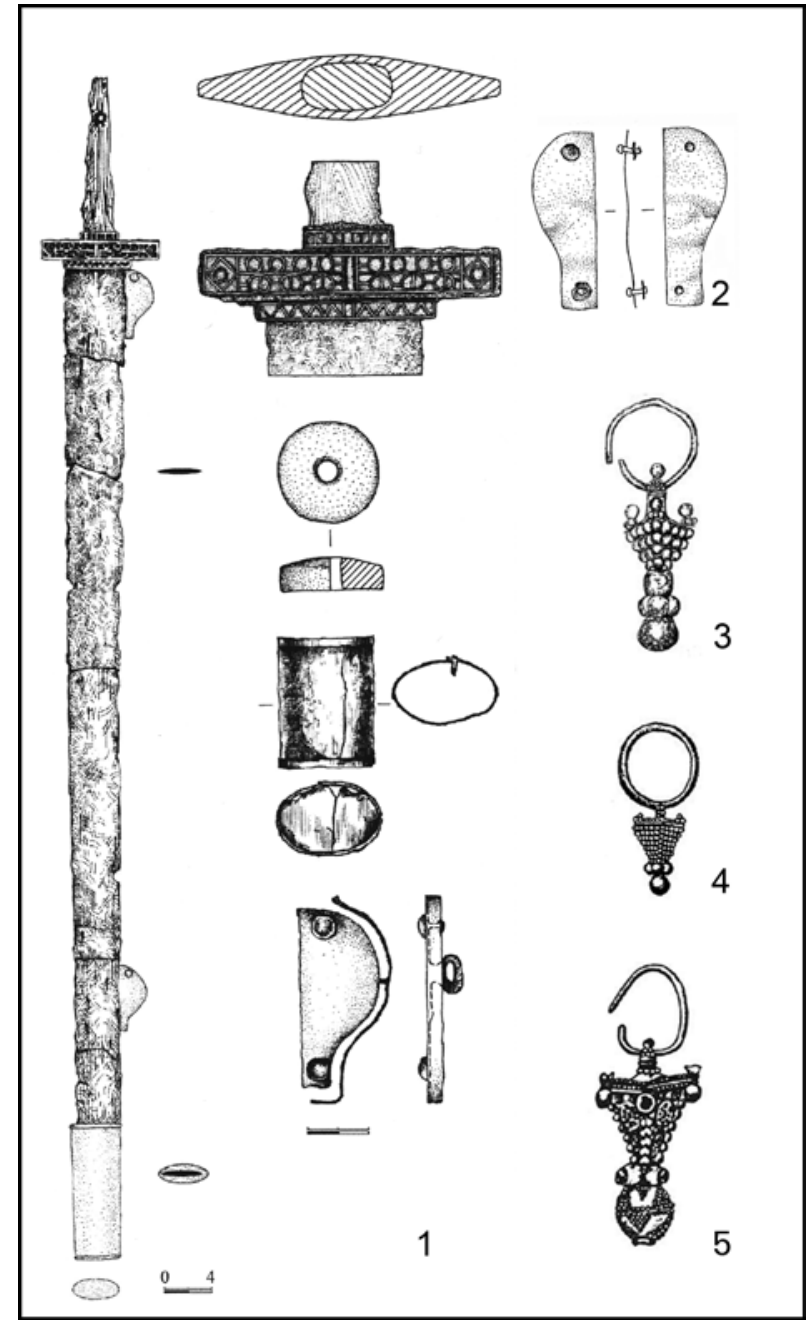

3. kép. A szegvár-sápoldali mellékletek kelet-európai párhuzamai: 1. Vostočny Malai II, 1. kurgán, 12. sír; Liventsovsky VII, 35. kurgán; 3. Kelegeâ; 4. Artsybaševo; 5. Glodosy (LIMBERIS-MARČENKO 2012; BEZUGLOV-ILÛKOV 2007 és BALOGH 2014 nyomán)

Fig. 3. Eastern European analogies of the grave goods in Szegvár-Sápoldal: 1. Vostochny Malai II, Mound 1, Grave 12; Liventsovsky VII, Mound 35; 3. Kelegeâ; 4. Artsybaševo; 5. Glodosy (after LIMBERIS-MARČENKO 2012; BEZUGLOVILÛKOV 2007 and BALOGH 2014)

Övgarnitúra. A préselt díszítetlen szíjvégekkel ellátott sok mellékszíjas övek párhuzamai nem ismertek keleten. A modern kutatás szerint az ilyen szerkezetú övek előképei a Mediterráneumban keresendők. ${ }^{46}$ Véleményem szerint ezt az övszerkezetet az avarok a bizánci birodalom lakóitól adoptálták, melyet aztán a saját ízlésvilágukhoz igazítottak. ${ }^{47}$

46 BÁLINT 2000.

47 Ez a hipotézis még természetesen további kutatásokat igényel. A késő avar korból hasonló folyamatokról számol be: DAIM 2001.
Kengyel. A kora avar kori tiszántúli népesség körében a kengyel eredetileg ismeretlen lehetett. ${ }^{48}$ Emiatt a tárgytípus megléte az egyes temetkezések esetében kronológiai jelentóséggel bír, az adott temetkezés ugyanis nem keltezhetó a 7. század elé. ${ }^{49}$ A Sivašovka-típusú temetkezésekben a kengyel megléte meglehetősen ritka, kevesebb, mint egy tucat sírból ismert a tárgytípus előkerülése. ${ }^{50}$ Nikolai Khrisimov szerint a kengyelek a Sivašovka-típusú temetkezések minden kronológiai fázisában jelen vannak. ${ }^{51}$ Mivel a tárgytípus hiányzik az egyértelmúen a 6 . századra keltezhető temetkezésekből, ezt a keltezést a 7. századra szúkíthetjük. Az Altaj vidékén a vasból készült kengyelek a Kyzyl-Taš-horizontban jelentek meg. Az újabb orosz kutatás szerint az időszakból elsősorban a hurkos fülú darabok ismertek, bár szórványosan a hosszú fülú típussal is találkozhatunk (1. kép 4-8). ${ }^{52}$

Lószerszámveretek. A Bóna István által rekonstruált lószerszámot rozetták és rovátkolt szegélyú szíjvégek díszítették. ${ }^{53}$ Habár régészeti bizonyítékunk kevés van rá, a rozettákkal súrún díszített lószerszám a képi források alapján elterjedt lehetett a kora középkori Közép-Ázsiában. ${ }^{54}$

A kelet-európai sztyeppén a viszonylag nagyszámú lovas temetkezés ellenére kevésból ismerünk lószerszámvereteket, melyek elsősorban az egész lovat tartalmazó sírokból kerülnek elő. Vostočny-Malai II 1. kurgán 12. sírjában lapos kerek veretek díszítették a kantárzatot. ${ }^{55}$ Ennek egy speciális változatát képviseli a vinogradnoei 5. kurgánban talált temetkezés, ahol a kerek veretek üvegberakásosak voltak. ${ }^{56}$ A lószerszám egy másik típusához tartoznak azok az esetek, ahol a kantárt maszkos veretekkel díszítették. Erre példaképpen Sivašovka 3. kurgánjának 2. sírját említhetjük. ${ }^{57}$

A kora avar korból ismert lószerszámtípusok az utóbbi években a Balkánról is ismertté váltak. A kelet-bulgáriai Bâla település melletti Szent Atanasz-csúcson lévő erődben egy négykaréjos

48 A sírokból való hiányuk azonban deponálási szokásokkal is magyarázható.

49 LŐRINCZY 1998, 345.

50 KHRISIMOV 2013.

51 KHRISIMOV 2013, 379.

52 TIŠKIN-SEREGIN 2011, 18.

53 Vö. BÓNA 1979, 11, 4. kép.

54 BÓNA 1980, 57-59, Abb. 11-13. Az ikonográfiai ábrázolásokkal kapcsolatban legutóbb Csuthy András hívta fel a figyelmet arra, hogy az idóben és térben távoli párhuzamokat korlátozottan lehet felhasználni az avar lószerszám rekonstrukciójához. CSUTHY 2016, 181.

55 LIMBERIS-MARČENKO 2012, 424; 428, ris. 9:10.

56 ORLOV-RASSAMAKIN 1996, 103-107.

57 KOMAR-KubYŠEV-ORLOV 2006, 292-293. 


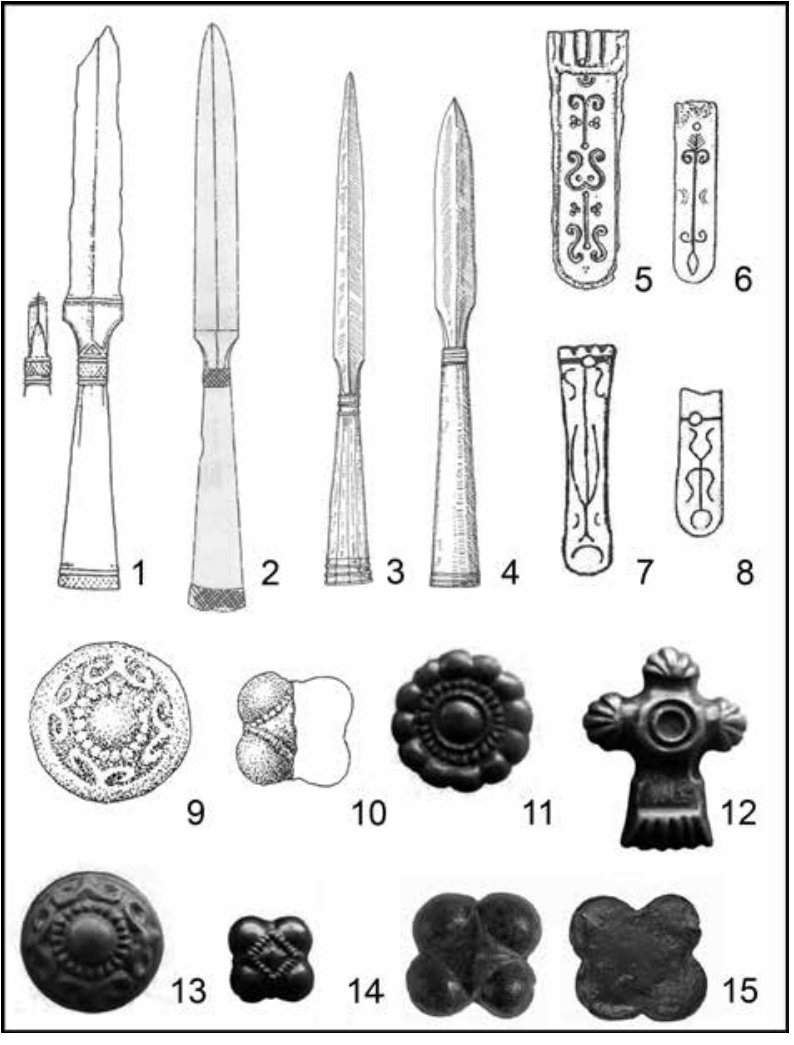

4. kép. Kora avar kori tárgytípusok, valamint nyugat- és déleurópai párhuzamaik: 1. Szentendre-Pannónia-dúlő; 2. Selenča (Bácsújfalu, SRB)-Belterület; 3. Unterensingen; 4. Schretzheim 339. sír; 5. Drevnâ (Marcianopolis); 6. ÉszakkeletBulgária; 7. Obyrtsi; 8. Čerentsa; 9-10. Felnac (Fönlak, RO); 11-14. Délkelet-Szerbia, a Cerovica-Knjazevac út közelében; 15. Bâla-Sv. Atanas (CSIKY 2015, vON FREEDEN 1991, DASKALOV 2012, RÁCZ 2014, RAŠKOvić 2016 és YoTOv 2013 nyomán)

Fig. 4. Early Avar finds and their Western and Southern European analogies: Szentendre-Pannónia-dúlő; 2. Selenča (Bácsújfalu, SRB)-Belterület; 3. Unterensingen; 4. Schretzheim, Grave 339; 5. Drevnâ (Marcianopolis); 6. Northeastern Bulgaria; 7. Obyrtsi; 8. Cherentsa; 9-10. Felnac (Fönlak, RO); 11-14. Southeastern Serbia, near the road between Cerovica and Knjazevac; 15. Bâla-Sv. Atanas (after CsIKY 2015, VON FREEDEN 1991, DASKALOV 2012, RÁCZ 2014, RAŠKOVIĆ 2016 and YOTOV 2013)

veret verötöve került elő (4. kép 15). ${ }^{58}$ Valeri Yotov az erőd pusztulását egy 614-es avar-szláv támadással kötötte össze. ${ }^{59}$ Kelet-Szerbiában, a Cerovicából Knjazevac felé vezető út mentén egy préselőtövekből álló depóleletet találtak, melyben többek között még egy négykaréjos és egy lóhere alakú veret, valamint rozetták készítésére szolgáló minták voltak (4. kép 11-14). ${ }^{60}$ Véleményem szerint a fenti adatok alapján a lószerszámveretek esetében nem zárhatunk ki egy közép-

\footnotetext{
58 Yотоv 2013, 436, ris. 8.

59 Yotov 2013, 429

60 RAŠKović 2016, 48, tabl. VIII. 1-3; 6.
}

európai-balkáni eredetet sem, ennek bizonyítására azonban még több adatra van szükségünk. ${ }^{61}$

A lószerszámhoz tartozó "tamgás" szíjvégek kapcsán megkérdőjelezhető, hogy a díszítés valóban nemzetségjegyekre utalna. Ezt támasztja alá, hogy a balkáni erődökből sorra kerültek elő tarsolyokhoz és övekhez tartozó, tamgás motívumokkal díszített „Martynovka-típusú” szijvégek (4. kép 5-8). ${ }^{62}$ Esetükben sokkal inkább stilizált növényi ornamentikáról van szó.

Szijszorító. ${ }^{33}$ A csontból vagy agancsból készült, két fúzőlyukkal ellátott szíjbújtatók két méretben ismertek. Míg a 2,8-4 cm-es darabok a lószerszámhoz tartozhattak, addig a sápoldali 6 cm-es darab az övön volt. ${ }^{64} \mathrm{~A}$ tárgytípus összes publikált példánya a Tiszántúlról került elö, ezért azt a tiszántúli kelet-európai eredetû́ népesség jellemző mellékleteként értékelhetjük. ${ }^{65}$ Bóna a jelentős számú belső-ázsiai párhuzam alapján a tárgytípust onnan eredeztette. A szíjszorítók a Bulan-Koby-kultúra és Tuvában a 3-5. századra keltezett Kokel-kultúra területén is felbukkantak. ${ }^{66}$ A tárgytípus nagyobb mennyiségben az Altaj vidékén a Kyzyl-Taš-horizontban is megvan, ebben az időszakban kizárólag a lószerszámhoz tartoztak (1. kép 11-13). ${ }^{67}$ Ha szórványosan is, de a szíjbújtatók Kelet-Európából is ismertek, példaként Avilovka 1. kurgánja ${ }^{68}$ vagy Matûhin bugor 12. sírja ${ }^{69}$ említhető.

$P$ alakú függesztófüles kard. A P alakú függesztőfüles kardok és tőrök Japántól Itáliáig kisebb gócokban terjedtek el. A kínai és korai példányok kapcsán korábban felmerült, hogy ezek a TávolKeletről származnak, de az ottani darabok a kelet-európaiakkal egyidősek. ${ }^{70}$ További különbség, hogy az itteni kardokon a karikás végú markolat és a $\mathrm{P}$ alakú függesztôfül egyszerre túnik fel, holott a Kárpát-medencében és Kelet-Európában ez nem ismert. A tárgytípus a 6 . század közepére keltezhető két leletegyüttesben, a Liventsovsky VII 35. kurgánjában (3. kép 2), valamint a Vostočny Malai II 1. kurgán, 12. sírban (3. kép 1) már megvan. ${ }^{71}$ Ezen korai darabokon kívül még egy fél tucat esetben ismert a $\mathrm{P}$ alakú függesztófül megléte, így a Kárpát-medencét leszámítva a

61 Ezt korábban már Rácz Zsófia is felvetette. RÁCZ 2014, 76.

62 DASKALOV 2012, 247, obr. 77:1-21; 248, obr. 78:1-18.

63 Bóna csontfüggesztőként foglalkozik a tárgytípussal. BÓNA 1980, 52-54.

64 LŐRINCZY 2015, 162.

65 LŐRINCZY 2015, 162.

66 MATRENIN 2017, 95.

67 TIŠKIN-SEREGIN 2011, 22.

68 RAŠEV 2005, 247, tabl. 12:3.

69 IŠAEV-SMOLÂK 2017, 165, ris. 4:25.

70 КосH 1998, 591-594.

71 KAZANSKI 2016, 109; KAZANSKI 2017, 68. 
Sivašovka-típusú temetkezésekben találkozunk legtöbbször a tárgytípussal. ${ }^{72}$

Lándzsa. A nádlevél alakú lándzsákat a kutatás sokáig az avarság első generációjához kötötte. ${ }^{73}$ A fegyvertípusnak a belső-ázsiai - elsősorban a türk - harcászatban betöltött szerepére a sziklarajzokon megörökített ábrázolások utalnak. ${ }^{74}$ Ennek ellenére a korai leletegyüttesek nem tartalmaznak lándzsákat, a Kyzyl-Taš-horizont lelőhelyein a tárgytípus csak egy alkalommal egy miniatúr példányként fordul elő. ${ }^{75}$

Kelet-Európában kevés lándzsa ismert. A korai lelőhelyek közül Liventsovsky VII 35. kurgánjában talált áldozati leletből származik egy egyedi, kannelúrázott köpújú példány. ${ }^{76}$ A 6-7. századra datált temetkezések közül Matûhin bugor 12. sírjából származik egy másik darab. A lándzsacsúcs a padmaly belső falánál volt, ami arra utal, hogy a fegyvert nem egészben, hanem vagy kettétörve, vagy csak a lándzsacsúcsot helyezték a sírba. ${ }^{77} \mathrm{Ez}$ párhuzamba állítható a tiszántúli temetkezésekkel, ahol a fegyver - ellentétben a Dunántúllal, ahol a lándzsát a ló mellé helyezték - a halott mellett, annak a bal karjánál vagy a fejénél található. ${ }^{78}$

Páncélrészlet. A páncéllemezek sírba helyezése a Bulan-Koby-kultúra 3-4. századra datált temetkezéseiben már tetten érhető. A Kárpát-medencéhez hasonlóan ezek nagy számban fordultak elő női és gyermeksírokban is. ${ }^{79}$ Ezzel szemben a Kyzyl-Taš-horizontban páncélok kizárólag áldozati leletekből kerültek elő. ${ }^{80}$ Bóna István az avar korban általánosnak mondható hét páncéllemez sírba helyezését is Ázsiából eredezteti, jóllehet csak három konkrét példánál figyeltek meg 6-7 darabot. ${ }^{81}$ A Kyzyl-Taš-horizont még egy lelóhelyénél dokumentáltak hasonló jelenséget (1. kép 14). ${ }^{82}$

A nehézlovas harcmodort Florin Curta kizárólag a belső-ázsiai avarok sajátjának tartotta, míg a 6. századi kelet-európai nomádokra szerinte csak a könnyúlovasság használata volt a jel-

72 KOMAR-KuBYŠEV-ORLOV 2006, 282.

73 CsIKy 2016, 210. Újabban a nádlevél alakú lándzsahegyek nyugati kapcsolatai kerültek előtérbe (4. kép 1-4), ám a Meroving- és a Kárpát-medencei párhuzamok kapcsolata még nem teljesen világos. CSIKY 2016, 210.

74 KubareV 2017, 164-165.

75 TIŠKIN-SEREGIN 2011, 25.

76 BEZUGLOV-ILÛKOV 2007, 48, ris. 9:1.

77 IŠAEV-SMOLÂK 2017, 163, ris. 3:11.

78 LŐRINCZY 2015, 160-161.

79 SoENOV-KONSTANTINOV-TRIFANOVA 2016, 144.

80 TIŠKIN-SEREGIN 2011, 26.

81 BÓNA 1980, 45.

82 Kok-Paš 1. kurgán (TišKIN-SEREGIN 2011, 27, ris. 5:12). A szerzők erre az időszakra keltezik Kudyrge 13. ogradkát is (1. kép 15). (TIŠKIN-SEREGIN 2011, 27, ris. 5:13). lemző. ${ }^{83}$ Elmélete a régészeti leletek tükrében azonban nem állja meg a helyét. Vostočny Malai 1. kurgán, 12. sír és Matûkhin bugor 12. sír egyaránt teljes páncélt tartalmazott. ${ }^{84}$ Egy darab lamella került elő Tsarsky kurgan lelőhelyről, ami alapján a páncél szimbolikus deponálása KeletEurópában sem volt ismeretlen..$^{85}$

\section{Összefoglalás}

A szegvár-sápoldali 1. sír a temetkezési szokásait tekintve jól beleillik a már több kutató által körvonalazott tiszántúli kora avar kori népességbe. A csoport temetkezési rítusainak kiváló párhuzamai ismertek a 6-7. századi Kelet-Európából. Az általunk vizsgált sír esetében a tájolásnak, a részleges és a teljes lovas temetkezésnek ismert innen analógiája. A fülkesírokat - korabeli párhuzamok híján - helyi fejlődés eredményének tarthatjuk. Szerkezetét tekintve - akna és fülkerész térben elválasztva - a padmalyos sírokkal rokonítható. A kettő között átmenetet képez a khristoforovkai sír. A több állat sírba helyezése a kora avar kori Tiszántúlon csak a tiszántúli népesség magterületére, a KörösTisza-Aranka közének folyó menti területeire, illetve később a Nyíri-Mezőségre jellemző. ${ }^{86}$

Míg a temetkezési szokások a sápoldali sír esetében egy irányba, a kora avar kori Tiszántúl és azon keresztül Kelet-Európa felé mutatnak, addig a mellékletek tekintetében már nem ennyire egyértelmú a helyzet. Az egyes tárgytípusokat elterjedésük alapján több csoportba sorolhatjuk. Az első csoportba azok a mellékletek tartoznak, melyek akár Belső-Ázsiából is származhatnak, ám azokat a kaganátuson belül is átvehették. Példaként a kengyeleket, a szíjszorítókat, a rozettás fejpántot és a hét lamella sírba helyezésének szokását említhetjük. A P alakú függesztőfülek és a gúlacsüngős fülbevalók (2. csoport) párhuzamai Kelet-Európában is megtalálhatók. A következőbe azok a tárgytípusok tartoznak, melyek a Kárpát-medencében alakulhattak ki (pl. díszítetlen szíjvégekkel ellátott sok mellékszíjas övgarnitúra, lándzsa). A lószerszámveretek ${ }^{87}$ és a tamgás

83 CURTA 2015, 78.

84 IŠAEV 2013; IŠAEV-SMOLÂK 2017.

85 ATAVIN 1996, 211.

86 LŐRINCZY 2015, 164.

87 A kézirat lezárása után jelent meg egy újságcikk egy NyugatKazahsztánban előkerült sztyeppei temetkezésről, amely aranyrozettákat is tartalmazott. A lelet némileg új megvilágításba helyezi a tárgytípus eredetének a kérdését, ezért a jelen tanulmányban sugallt Kárpát-medencei-balkáni eredet bizonyítása további kutatásokat igényel. Forrás: https://www. nur.kz/1736049-najdennyj-v-aktobe-zolotoj-celovekokazalsa-vozdem-plemeni-foto.html (utolsó megtekintés: 2018. 06. 10.) 
szíjvégek a Balkánról is ismert melléklettípusok, de az avar szállásterületen belül is rendkívül elterjedtek. Végezetül az ötödik csoportba tartoznak az általánosan elterjedt tárgyak, erre példaként a tegezakasztót hozhatjuk.

A fenti változatosságot az indokolja, hogy a lelóhely stratégiai elhelyezkedése miatt - a KörösTisza összefolyásának tágabb környezetében helyezkedik el - a szegvár-sápoldali temetőt használó közösség a Kárpát-medencén belül (és kívül?) széles körú kapcsolatokkal rendelkezhetett. A tárgytípusok közül csak néhány mutathat fel belsó-ázsiai analógiákat. Ennek nyomán a szegvári 1. sírt sokkal inkább közép-kelet-európai kontextusban kell értelmezni.

\section{IRODALOM}

Atavin, ANdrei G. / АтАвин, АндРей Г.

1996 Погребения VII - начала VIII вв. из Восточного Приазовья. In: Сташенков, Д. А. (отв. ред.): Культуры евразийских степей второй половины I тысячелетия н. э. Самара. 208-264.

BÁLINT, CSANÁD

1993 Probleme der archäologischen Forschung zur awarischen Landnahme. In.: Müller-Wille, M.-Schneider, R. (Hrsg.): Ausgewählte Probleme europäischer Landnahmen des Früh- und Hochmittelalters. Vorträge und Forschungen 41. Sigmaringen. 195-273.

2000 Bizánc és a 6-7. századi kisszíjjas övek (Byzantine and the small strapped belts from the VI-VII. centuries). Somogyi Múzeumok Közleményei (Kaposvár) 14, 41-92.

BALOGH CSILLA

2014 Az avar kori gúlacsüngős fülbevalók. Kuny Domokos Múzeum Közleményei (Tata) 20, 91-147.

BeREZUTSKIY, VALERIY D.-MASTYKOVA, ANNA V. / БЕРЕзУЦКИЙ, ВАЛЕРЙ̆ Д.-МАСтЫКОВА, АННА В.

2016 Погребение эпохи великого переселения народов на левобережье Среднего Дона. Краткие сообщения Института археологии (Москва) 245, 219-243.

BeZuglov, SERGei I.-IlûKOV, LeONID S. / БЕзУгЛОв, СЕРГЕЙ И.-ИЛЬЮКОВ, ЛЕОНИД С.

2007 Памятник позднегуннской эпохи в устье Дона. In.. Гугуев, Ю.К. (отв. ред). Средневековые древности Дона. Москва-Иерусалим. 25-48.

BÓNA, ISTVÁN

1979 A Szegvár-sápoldali lovassír - Adatok a korai avar temetkezési szokásokhoz. Archaeologiai Értesítő (Budapest) 106, 3-32.

1980 Studien zum frühawarichen Reitegrab von Szegvár. Acta Archaeologica Academiae Scientiarum Hungaricae (Budapest) 32, 31-95.

1990 Beiträge zum asiatischen Ursprung der awarenzeitlichen partiellen Pferdebestattungen. A Wosinsky Mór Múzeum Évkönyve (Szekszárd) 15, 113-123.

ČINDINA, LyUdMilÂ A. / ЧиндинА, ЛюдмилА A.

1977 Могильник Рёлка на Средней Оби. Томск.

С̆KHAIDZE, VIKTOR N. / ЧХАИДЗЕ, ВИКТОР Н.

2011 Раннесредневековые кочевнические погребения из Восточного Приазовья. Материалы и Исследования по Археологии Северного Кавказа (Армавир) 12, 115-140.

CSIKY, GERGELY

2015 Avar-Age Polearms and Edged Weapons. Classification, Typology, Chronology and Technology. East Central and Eastern Europe in the Middle Ages 450-1450 32. Leiden-Boston.

2016 Inner Asian or Byzantine? Lanceheads from Merovingian Cemeteries: A View from the Carpathian Basin. In: Bollók, Á.-Csiky, G.-Vida, T. (eds): Zwischen Byzanz und der Steppe. Archäologische und historische Studien. Festschrift für Csanád Bálint zum 70. Geburtstag. (Between Byzantium and the Steppe. Archaeological and Historical Studies in Honour of Csanád Bálint on the Occasion of His $70^{\text {th }}$ Birthday.) Budapest, 209-221.

CSUTHY ANDRÁs

2016 Ikonográfiai ábrázolások és rekonstrukciós lehetőségek az avar kori lószerszámzatra vonatkozóan (Iconography and possibilities of reconstruction about Avar age horse harness). In: S. Perémi Á. (szerk.): Hadak útján. Népvándorlás Kor Fiatal Kutatóinak XXIII. konferenciakötete. Veszprém, 2013. október 2-4. Veszprém, 178-192.

CURTA, FLORIN

2015 Avar Blitzkrieg, Slavic and Bulgar Raiders, and Roman Special Ops: Mobile Warriors in the 6th-century Balkans. In: Zimonyi, I.-Karatay, O. (eds): Eurasia in the Middle Ages. Studies in Honour of Peter B. Golden. Wiesbaden, 69-89. 
DAIM, FALKO

2001 Byzantine Belts and Avar Birds. Diplomacy, Trade and Cultural Transfer in the Eighths Century. In: Pohl, W.-Wood, I.-Reinitz, H. (Hrsg.): The Transformation of Frontiers. From Late Antiquity to the Carolingians. The Transformation of the Roman World 10, 143-188.

Daskalov, Metodi / Даскалов, Методи

2012 Колани и коланни украси от VI-VII век (от днешна България и съседните земи). София.

DerevÂNKo, YeVgeniÂ I. / ДеРевянко, ЕвГения И.

1988 Бараба в тюркское время. Новосибирск.

VON FREEDEN, UTA

1991 Awarische Funde in Süddeutschland? Jahrbuch des Römisch-Germanisches Zentralmuseums, Mainz (Mainz) 38/1. 593-627.

GARAM, ÉVA

2001 Funde byzantinischer Herkunft in der Awarenzeit vom Ende des 6. bis zum Ende des 7. Jahrhunderts. Monumenta Archaeologica Avarorum 5. Budapest.

GULYÁS BENCE

2015 Újabb adatok a kora avar kori Tiszántúl kelet-európai kapcsolataihoz (New results of research concerning the relations between Hungary and the Eastern European steppe in the Early Avar Period) In: Türk A. (főszerk.): Hadak útján. A népvándorláskor fiatal kutatóinak XXIV. konferenciája, Esztergom 2014. november 4-6. Studia ad Archaeologiam Pazmaniensia. A PPKE BTK Régészeti Tanszékének kiadványai 4. Budapest-Esztergom, 499-512.

IŠAEV, VADIM I. / ИШАЕВ, ВАДИМ И.

2013 Ранний образец восточноевропейского средневекого панциря (Защитный досплех раскопок в Краснодарском Крае) Краткие сообщения Института археологии (Москва) 228, 191-199.

IŠAEV, VADIM I.-SMOLÂK, A. R. / ИШАЕВ, ВАДИМ И.-СМОЛЯК, АЛЕКСАНДР Р.

2017 Раннесредневековый панцирь из могильника Матюхин Бугор (Ростовская область) Российская Археология (Москва) 2017:4, 160-174.

YOTOV, VALERI / Йотов, ВАЛЕРИЙ

2013 Эргастирий начала VII в. в византийской крепости на мысе св. Атанас в городе Бяла, Варненской области (предварительное сообщение) In: Домановский, А. Н. (сост.): Р Б. Сорочана (Нартекс. Вyzantina Ukrainensia. - Т. 2) Харьков, 426-439.

KAZANSKI, Michel M./ КАЗАНСКИЙ, МИХАИЛ M.

2016 Оногуры в пост-гуннское время на Дону. Дивногорский сборник (Воронеж) 6, 96-111.

2017 Tombes des élites steppiques de l'époque post-hunnique dans la région Pontique. Přehled výzkumů (Brno) 58:1, 65-84.

KHRISIMOV, NiKOLAi / ХРИСИМOB, H.

2013 Вторични могилни гробове със стремена от южноруските степи (VI-VII в.). Добруджа (Силистра-Добрич) 24-25, 355-380.

KOCH, ALEXANDER

1998 Überlegungen zum Transfer von Schwerttrag- und Kampfweise im frühen Mittelalter am Beispiel Chinesischer Schwerter mit P-förmigen Tragriemenhaltern aus dem 6-8. Jahrhundert n. Chr. Jahrbuch des Römisch-Germanisches Zentralmuseums, Mainz (Mainz) 45/2 (1999), 571-598.

KOMAR, AleKSEI V. / КомAP, АлЕКСей В.

2006 Погребение кочевника нач. VIII в. у села Журавлиха в Среднем Поднепровье. In.: Евглевский, А. В. (ред.): Степи Европы в эпоху средневековья, Т. 5. Хазарское время. Донецк, 403-412.

Komar, Aleksei V.-KubyŠEv, AnAtoly I.-Orlov, Ruslan S. / КомAP, АЛЕКсей В.-КУБЫШЕв, АНАтолиЙ И.ОрлОв, РУСЛАН С.

2006 Погребения кочевников VI-VII вв. из Северо-Западного Приазовья. In.: Евглевский, А. В. (ред.): Степи Европы в эпоху средневековья, Т. 5. Хазарское время. Донецк, 245-374.

KubAREV, GLEB

$2017 \quad$ Alttürkische Gräber des Altaj. Berlin.

Limberis, NATALiÂ Yu-MarČEnKO, IVAN I. / ЛИМБЕРИС, НАТАЛЬЯ Ю.-МАРчЕНКО, ИвАН И.

2012 Погребения эпохи великого переселения народов и раннего средневековья из курганов степного Прикубанья In: Шаров О. В. (отв. ред.): Петербургский Апокриф. Послание от Марка. Санкт-ПетерсбургКишинев, 417-441.

LŐRINCZY, GÁBOR

1992 Vorläufiger Bericht über die Freilegung des Gräberfeldes aus dem 6.-7. Jahrhundert in SzegvárOromdúlő. Weitere Daten zur Interpretierung und Bewertung der partiellen Tierbestattungen in der frühen Awarenzeit. Communicationes Archaeologicae Hungariae (Budapest) 81-124.

1994 Megjegyzések a kora avar kori temetkezési szokásokhoz (Fülkesíros temetkezés). In.: Lőrinczy G. (szerk.): A kőkortól a középkorig. Tanulmányok Trogmayer Ottó 60. születésnapjára. Szeged, 311-335. 
1998 Kelet-európai steppei népesség a 6-7. századi Kárpát-medencében. Régészeti adatok a Tiszántúl kora avar kori betelepüléséhez (Osteuropäische Steppenbevölkerung im 6. und 7. Jahrhundert im Karpatenbecken, Archäologische Beiträge zur frühawarenzeitlichen Einsiedlung des Gebietes jenseits der Theiß). A Móra Ferenc Múzeum Évkönyve-Studia Archaeologica (Szeged) 4, 343-372.

2015 Újabb adatok Hajdú-Bihar megye avar kori lelőhelyeihez I. Megjegyzések a terület kora avar kori történetéhez (New data on the Avarian Age sites of Hajdú-Bihar County I. Some notes on the Early Avarian Age history of the region). A nyíregyházi Jósa András Múzeum Évkönyve (Nyíregyháza) 57, 149-176.

2016 A tiszántúli VI-VII. századi sírok és temetők sajátosságai. A kora avar kori népesség továbbélése a VIIIX. században a Körös-Tisza-Maros közén (Characteristic features of $6^{\text {th }}-7^{\text {th }}$ century burials and cemeteries east of the Tisza. Survival of Early Avarian Age population between rivers Körös, Tisza and Maros). A nyíregyházi Jósa András Múzeum Évkönyve (Nyíregyháza) 58, 155-176.

MAtrenin, Sergei S. / МATPËHИН, СЕРГЕЙ C.

2017 Снаряжение кочевников Алтая (II в. до. н. э. - V в. н. э.) Барнаул.

NÉMETHI MÁRIA-KLIMA LÁSZLó

1992 A korai avar lovas temetkezések. A nyíregyházi Jósa András Múzeum Évkönyve (Nyíregyháza) 30-32 (1987-1989), 173-244.

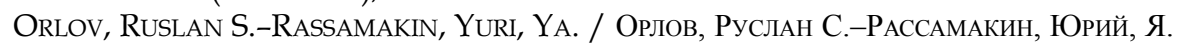

1996 Новые памятники VI-VII вв. из Приазовья. In: Приходнюк, О. М. (ред.): Материалы I тыс. н. э. по археологии и истории Украины и Венгрии. Киев, 102-116.

PRIHODNYUK, OLEG-FORMENKO, VictOR

2003 Early Medieval Nomads' Burials from the Vicinity of the Village of Hristoforovka, the District of Nikolaevo, Ukraine. Archaeologia Bulgarica (Sofia) 7:2, 107-116.

RÁCZ, ZsÓFIA

2014 Die Goldschmiedegräber der Awarenzeit. Monographien des Römisch-Germanischen Zentralmuseums 116. Mainz.

RAŠEV, RAŠO / PAшEB, РAшO

2005 Прабългарите през V-VII век. Велико Тырново.

RAŠKOVIĆ, DuŠAN / РАшКовИћ, ДушАН

2016 Низинска античка насеља и висинска рановизантијска налазишта у окружју Алексинца и Соко Бање. Караџић. Часопис за историју, етнологију, археологију и уметност (Алексинац) 8, 21-48.

Seregin, Nikolai N. / СеРегин, НиколАй H.

2013 Социальная организация раннесредневековых тюрок Алтае-Саянского региона и Центральной Азии. (По материалам погребальных комплексов) Барнаул.

Seregin, Nikolai N.-Matrenin, Sergey S. / СеРегин, НиколАЙ Н.-МatPËHИН, Сергей C.

2016 Погребальный обряд кочевников Алтая во II в. до н.э. - ХІ в. н. э. Барнаул.

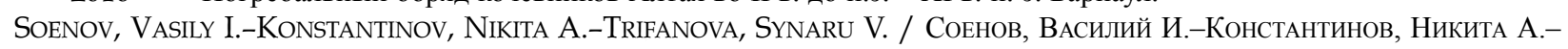
ТРИФАНОВА, СЫНАРУ В.

2016 Особенности детского погребального обряда могильника Степушка-2 на Алтае (Предварительное сообщение) Вестник Томского Государственного Университета (Томск) 404, 143-146.

STARK, SÖREN

2009 Some Remarks on the Headgear of the Royal Türks. Journal of Inner Asian Art and Archeology (Turnhout) 4, 119-133.

SZMONIEWSKI, BARTŁOMIEJ SZ. / ШMOHЕВСКИ, БАРТЛOMEЙ, Ш.

2016 Византийская монета и ее подражания (монета мертвых) на примере находок из погребенй Аварского каганата, на шелком пути и прилегающих территорий (VI-VIII вв.) Краткие сообщения Института археологии (Москва) 234, 254-274.

TišKin, AleKSei A.-Seregin, NiKolai N. / Тишкин, АЛЕксей A.-СеРегин, НиколАй Н.

2011 Предметный комплекс из памятников кызыл-ташского этапа тюркской культуры (2-я половина V - 1-я половина VI вв. н.э.): традиции и новации. Теория и практика археологических исследований (Барнаул) 6 , $14-32$.

2013 Китайские изделия археологических памчтников раннесредневековых тюрок Центральной Азии. Теория и практика археологических исследований (Барнаул) 7, 49-72. 


\section{THE CULTURAL CONTACTS OF THE GRAVE NR. 1 OF SZEGVÁR-SÁPOLDAL IN THE LIGHT OF THE RUSSIAN AND UKRANIAN RESEARCH}

\section{BENCE GuLYÁs}

István Bóna's articles about the Grave Nr. 1 of the Szegvár-Sápoldal cemetery are ones of the most influencing works ever written about the Early Avar Age. He used the grave to complete the fragmented written sources with archaeological data and offer a historical narrative. He considered the grave from Szegvár as a member of the first generation of the Avars in the Carpathian Basin, therefore he looked for analogies with few exception in Central and Inner Asia. In the last 40 years, since the time of Bóna's research, the Soviet and Post-Soviet archaeology has developed dramatically; henceforth his results require some revision. In my present article, I propose some points of view to use the analogies.

The population settled in this area in the Early Avar period has certain funeral customs which distinguish them from the other peoples of the Avar Khaganate. At the same time, these customs are common in the Eastern European steppe. Despite the archaic elements, there are also some customs - e.g. the accumulation of sacrificial animals, the coffin reinforced with iron nails and placing coin in the grave - that could be the result of an internal development. The cultural contacts of the material culture are influenced by the geographical location of the site. The cemetery is located not so far from one of the most important crossing point on the Tisza River, therefore the community that used it could have been interested in the trade. Among the grave goods, there is not any object, which has analogies only in Asia. At the same time, the significance of these analogies from Eastern Europe and the Carpathian Basin or even the Balkan peninsula is greater, so we should examine the grave from Szegvár in an East-Central European context. 